\title{
Klímaváltozáshoz kapcsolódó természeti kockázatok helyi léptékủ elemzése és a társadalmi felkészültség vizsgálata Közép- és Délkelet-Európában - Egy transznacionális projekt eredményei
}

\section{Local level analysis of climate-change-related natural risks and social preparedness in Central and South East Europe - The results of a transnational project}

\author{
FÖLDI ZSUZSA, UZZOLI ANNAMÁRIA, SIK ANDRÁS, \\ PERGE KINGA, HORVÁTH ANIKÓ, \\ CZIKORÁNÉ BALÁZS ERIKA, LÁSZLÓ PÉTER
}

FÖLDI Zsuzsa: tudományos munkatárs, MTA Közgazdaság- és Regionális Tudományi Kutatóközpont, Regionális Kutatások Intézete, Budapest; foldizsu@hotmail.com UZZOLI Annamária: tudományos munkatárs, MTA Közgazdaság- és Regionális Tudományi Kutatóközpont, Regionális Kutatások Intézete, Budapest; uzzoli@rkk.hu

SIK András: egyetemi adjunktus, Eötvös Loránd Tudományegyetem, Természetföldrajzi Tanszék, Budapest; sikandras@gmail.com PERGE Kinga: tű. főhadnagy, kiemelt főelőadó, Belügyminisztérium Országos Katasztrófavédelmi Főigazgatóság Informatikai Főosztály, Budapest; gis.seerisk@katved.gov.hu HORVÁTH Anikó: SEERISK projekt szakmai munkatárs, Belügyminisztérium Országos Katasztrófavédelmi Főigazgatóság, Budapest; aniko.horvath@katved.gov.hu CZIKORÁNÉ BALÁZS Erika: tű. alezredes, kiemelt főelőadó, Belügyminisztérium Országos Katasztrófavédelmi Főigazgatóság Informatikai Főosztály, Budapest; gis.seerisk@katved.gov.hu LÁSzLó Péter: tű. főhadnagy, kiemelt főelőadó, Belügyminisztérium Országos Katasztrófavédelmi Főigazgatóság Informatikai Főosztály, Budapest; gis.seerisk@katved.gov.hu

KULCSSZAVAK: globális klímaváltozás, kockázati térkép, társadalmi klímatudatosság és felkészültség, Közép- és Délkelet-Európa, SEERISK, térinformatika, polgári védelem

ABSZTRAKT: Az elmúlt években felértékelödött a globális klímaváltozás regionális hatásainak kutatása, s ezzel párhuzamosan az időjárási szélsőségek okozta természeti veszélyhelyzetek társadalmi következményeinek minél pontosabb feltérképezése. Helyi szinten a természeti kockázatokkal összefüggésben a társadalom növekvő sérülékenysége jelent kihívásokat, így egyre nagyobb az igény a társadalom és a gazdaság részéről a felkészüléssel és megelőzéssel kapcsolatos információkra. Az Európai Unió támogatásával több olyan nemzetközi projekt valósult meg a Kárpát-medencében, amely különböző szempontok alapján vizsgálja a klímaváltozás okait és hatásait (pl. CARPATH CC, korábban ADAM, CECILIA, ENSEMBLES, PRUDENCE stb.). Ezek közül a SEERISK projekt kilenc közép- és délkelet-európai ország részvételével működik 2012 óta, és fő célkitű-

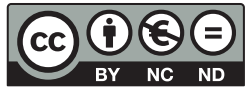


zése egységes kockázatértékelési módszertan kialakítása a klímaváltozás következtében felerősödő természeti veszélyhelyzetekre való megfelelő katasztrófavédelmi felkészülés céljából. A tanulmány elsődleges célja bemutatni azokat az eredményeket és tapasztalatokat, amelyek közös alapokra helyezhetik a klímaváltozással kapcsolatos kockázatok felmérését, térképi ábrázolását, az intézményi és lakossági felkészülést, a természeti veszélyhelyzetek kezelését. Az eredmények feldolgozása mellett részletesen ismertetjük a kockázatértékelési és a közösségi klímaadaptációs képesség elemzésére irányuló társadalomtudományi módszereket.

Zsuzsa FÖLDI: research fellow, Institute for Regional Studies, Centre for Economic and Regional Studies, Hungarian Academy of Sciences, Budapest; foldizsu@hotmail.com

Annamária UZZOLI: research fellow, Institute for Regional Studies, Centre for Economic and Regional Studies, Hungarian Academy of Sciences, Budapest; uzzoli@rkk.hu

András SIK: assistant professor, Department of Physical Geography, Eötvös Loránd University, Budapest; sikandras@gmail.com

Kinga PERGE: Lt, GIS officer, IT Department GIS \& Telecommunication, National Directorate General for Disaster Management, Ministry of the Interior, Budapest; gis.seerisk@katved.gov.hu

Anikó HORVÁTH: SEERISK Project Member, National Directorate General for Disaster Management, Ministry of the Interior, Budapest; aniko.horvath@katved.gov.hu

Erika BALÁZS CZIKORA: Lt-Col, GIS officer, IT Department GIS \& Telecommunication, National Directorate General for Disaster Management, Ministry of the Interior, Budapest;

gis.seerisk@katved.gov.hu

Péter LÁSZLó: Lt, GIS officer, IT Department GIS \& Telecommunication, National Directorate General for Disaster Management, Ministry of the Interior, Budapest; gis.seerisk@katved.gov.hu

KEYWORDS: global climate change, risk mapping, awareness and preparedness, Central and South East Europe, SEERISK, GIS, civil protection

ABSTRACT: In the past decades, topics related to socio-economic impacts of climate change and to mapping of potential natural risks caused by extreme climatic situations have been put high on the researchers' agenda. Extreme weather conditions increase the vulnerability of local communities, who are in need of proper climate adaptation and mitigating strategies. There have been a number of transnational projects in the Carpathian Basin financed by different EU funding schemes, which examined the causes and impacts of climate change from various perspectives (e.g. CARPATH CC, earlier ADAM, CECILIA, ENSEMBLES, PRUDENCE, etc.).

SEERISK, including nine Central and South-East European countries, is a SEE (South East Europe Transnational Cooperation Programme) funded project, commenced in 2012. The project objectives were elaborating, testing and sharing uniform methodologies for mapping risks related to climate change, examining the social consequences, and formulating recommendations for community strategy building which are applicable across the Danube region. The project also aimed to share experience and prepare local communities for extreme weather situations and for managing natural disaster situations using adaptable innovative methods.

The present study aims at presenting the major outcomes of the SEERISK project. The main ambition of the paper is to present the applicability of the methodologies used in social sciences for the problem field of climate change and also the way these methods can be combined with natural science and GIS methods in order to formulate an integrated project framework. The combined methodology was applied in six case study areas.

Common risk assessment methodology integrates the European Commission's Risk Assessment and Mapping Guidelines for Disaster Management. Each case study area prepared a risk matrix focusing on the natural hazard that they chose as the most relevant for their area and developed a risk scenario describing the natural hazard and its consequences. The methodology offers various alternative solutions for implementing the risk assessment process, especially for developing risk maps. 
Examining the social aspect of climate change involved the assessment of awareness and preparedness of individuals and stakeholders in the pilot communities. The social survey of the project reflected on the awareness and preparedness of inhabitants and institutions in the pilot communities regarding climate-change-related natural hazards. The approach and behaviour of the inhabitants were studied by a non-representative questionnaire survey, while the approach of the institutions and decision makers was revealed by conducting interviews and by scrutinising local planning documents of the municipalities concerned. The questionnaire survey served to build firm knowledge about the local people's awareness of climate change impacts on their life and their preparedness for related natural hazards. Personal interviewing and analysing planning documents contributed to understanding the administrative and institutional approach and reaction to climate change and its consequences in the Danube macro-region.

By combining risk assessment and social surveys, gaps were identified between the actual exposure to hazards and the level of community preparedness. Finally, a collection of recommendations was compiled in a guideline of climate change mitigation and adaptation useful for decision makers, academics and individuals who are all equally exposed to the impacts of global climate change.

\section{Bevezetés}

A klímaváltozás befolyásolja az életminőséget, komoly kihívást jelent a gazdaság és a társadalom számára, egyben jelentős alkalmazkodást igényel a közösségek részéről (Pappné Vancsó 2014). A klímaváltozás egyik legsúlyosabb következménye a szélsőséges időjárási helyzetekből kialakuló katasztrófahelyzet, amely veszélyezteti az emberi életet és a helyi közösségek által létrehozott értékeket. Fontos tehát helyi szinten ismerni egyrészt a klímaváltozásból fakadó potenciális természeti kockázatokat, másrészt a helyi társadalom (a lakosság és a döntéshozók) felkészültségében és adaptív képességében jelentkező hiányosságokat, az ezeket meghatározó és befolyásoló tényezőket. A problémák megoldásában, a hiányosságok felszámolásában, a megfelelő javaslatok és intézkedések kidolgozásában lokális és a nemzetközi szinten egyaránt egyre szükségesebbé válik az integrált gondolkodás, a klíma- és társadalomkutatók, a szakpolitikusok és a katasztrófavédelem operatív szereplőinek együttműködése.

Az utóbbi években a klímaváltozást okozó tevékenységek korlátozása (mitigáció) mellett kulcskérdéssé vált a klímaváltozás hatásaihoz való alkalmazkodás (adaptáció), ami a helyi közösségeket, az egyéneket, a gazdaságot és a gazdasági szereplőket, valamint az infrastruktúrát és a különböző szolgáltatásokat egyaránt érinti. A tét rendkívül nagy a városi és vidéki térségek számára: a megélhetés biztosítása, az életminőség javítása, az infrastruktúra védelme, a fenntartható növekedés megvalósítása, a természeti környezet megóvása, a kulturális értékek fenntartása stb. Mindezek egyre inkább feltételezik a közösségek részéről a klímaváltozás helyi következményeihez - a szélsőséges időjárási helyzetekhez - való fokozott alkalmazkodást, az eredményesebb megelőző lépéseket és a tudatosabb felkészülést. 
Az Európai Unió és részben ennek nyomán a hazai kormányzat és a felelős szakmai szervezetek változatos formában és eredménnyel, de mindenképpen kiemelt kérdésként kezelik a klímaváltozást, ${ }^{1}$ a mitigáció és adaptáció lehetőségeit és mindennek a katasztrófavédelmi vonatkozásait. Többféle forrásból finanszírozott nemzeti és nemzetközi kutatási projektek különféle megközelítésben, más-más prioritások mentén foglalkoznak a témakörrel, például hol csak a klimatikus jelenségek rendszerezésére, hol az okok vizsgálatára, hol pedig a következmények prognosztizálására és részben kezelésére koncentrálnak. A jelen tanulmány által feldolgozott transznacionális SEERISK projekt célja a klímaváltozás hatásaként jelentkező természeti veszélyhelyzetek felmérése, a helyi közösségek felkészültségének vizsgálata, valamint az ezek összehasonlításával szükségesnek ítélt tevékenységek (megelőzés és felkészülés) hatékonyabbá tétele (SEERISK 2014a, 2014b).

A tanulmány a projekt legfontosabb eredményeit és következtetéseit mutatja be, valamint részletesen tárgyalja a kutatási együttműködés keretében kidolgozott komplex módszertan elméleti és gyakorlati vonatkozásait. A megvalósult projekt feladatai között nem szerepelt az éghajlatváltozás globális jelenségének és helyi hatásainak tudományos bizonyítása, így a cikk sem tér ki ezek magyarázatára. A projektterv végrehajtása során a partnerországok döntése volt, hogy az általuk definiált értékelési szempontok szerint (pl. érintett lakosok száma, hőséghullámhoz kötődő orvosi beavatkozások száma stb.) milyen természeti veszélyhelyzeteket választanak ki esettanulmányuk elkészítéséhez, amelyek adott mintaterületen tipikusak, az éghajlatváltozással összefüggésbe hozhatók és helyi szinten a katasztrófavédelem számára speciális kihívásokat jelentenek. Szintén hangsúlyozzuk, hogy a projekt során kidolgozott és egységes elveken alapuló közös módszertan újszerüsége nem az alkalmazott természet- és társadalomtudományi vizsgálati technikákban rejlik, hanem ezek szisztematikus egymásra épülésében, a természeti és társadalmi hatásokra egyaránt reflektáló szemléletében és kisebb módosításokkal más országok katasztrófavédelmi szervezetei számára is adaptálható rendszerében.

\section{A globális klímaváltozás helyi hatásainak vizsgálati módszertana}

A Délkelet-európai Transznacionális Együttműködési Program (SEE Program) által finanszírozott SEERISK projekt ${ }^{2}$ 2012-ben indult, kilenc partnerország ${ }^{3}$ és tizenkilenc intézmény (önkormányzatok, meteorológiai szolgálatok, katasztrófavédelmi szervezetek stb.) együttműködésével. A stratégiai jelentőségü kutatás gyakorlati vonatkozásai (pl. esettanulmányok elkészítése, katasztrófavédelmi szimulációk) hat közép- és délkelet-európai mintaterületen valósultak meg (1. táblázat). A kiválasztott mintaterületeken végrehajtott esettanulmányok pilot- 
1. táblázat: A SEERISK projekt mintaterületeinek alapadatai The basic data of the SEERISK pilot sites

\begin{tabular}{llcc}
\hline \multicolumn{1}{c}{ Ország } & \multicolumn{1}{c}{ Mintaterület } & $\begin{array}{c}\text { Települések } \\
\text { száma }\end{array}$ & $\begin{array}{c}\text { Teljes } \\
\text { lakosságszám }\end{array}$ \\
\hline Bosznia-Hercegovina & Szarajevó-Ilidža & 2 & 71892 \\
Bulgária & Velingrad & 24 & 40707 \\
Magyarország & Siófok & 1 & 24662 \\
Románia & Arad & 1 & 147922 \\
Szerbia & Magyarkanizsa (Kanjiža) & 13 & 25950 \\
Szlovákia & Szenice (Senica) & 3 & 20063 \\
\hline Összesen & 6 & 44 & 294496 \\
\hline
\end{tabular}

Forrás: SEERISK 2014b, 83.

tanulmányként is értelmezhetők, hisz a kidolgozott módszertan alkalmazására ezeken a területeken került sor első alkalommal, s az eredmények referenciaként szolgálnak más országok számára hasonló kutatások megalapozásához.

A mintaterületek kiválasztása alapvetően a partnerországok feladata volt több szempont figyelembevételével. Például: az adott mintaterület mennyire illeszkedik és felel meg a projektben való részvétel feltételeinek; a kiválasztott természeti veszélyhelyzet gyakorisága és intenzitása valóban a klímaváltozással kapcsolatba hozható helyi szélsőséges időjárási helyzetekhez kapcsolódik-e; ezzel összefüggésben fennáll-e a katasztrófahelyzet kialakulásának veszélye; egyáltalán rendelkezésre állnak-e meteorológiai és hidrológiai adatok a kockázatfelméréshez; a projekttervben definiált szereplők mindegyikével el lehet-e végezni a helyi vizsgálatokat; a kiválasztott természeti veszélyhelyzet mennyire tekinthető tipikusnak a délkelet-európai térségben stb. Mindezen szempont és feltétel együttesen eredményezte a hat mintaterület kijelölését. Ezek léptéke a településtől a több településből álló nagyobb területekig (általában a járási szintig) terjedt, ezért a projekt keretében elvégzett kérdőíves felmérés nem tekinthető valamennyi mintaterületen reprezentatívnak. Ugyanakkor az esettanulmányok eredményeinek összehasonlíthatósága érdekében a partnerországok egységes elvek és azonos útmutató alapján végezték el a kockázatértékelés folyamatát és bonyolították le a társadalmi vizsgálatokat, de minden esetben a módszerek alkalmazását és a vizsgálatok elvégzését összehangolták a helyi adottságokkal, feltételekkel. A természeti veszélyek és a veszélyeztető tényezők széles körét számba vevő közös módszertannal az egyes mintaterületeken szerzett eredmények, tapasztalatok így alkalmasak az általános következtetések megállapítására, amelyek pedig a szakpolitikai döntéshozatal számára megfogalmazott javaslatok alapját képezik. A projekt keretében kidolgozott módszertan elsődlegesen nem a különböző vizsgálati léptékű mintaterületek összehasonlítására szolgál, hanem a Duna makrorégióban található országok módszertani ajánlásként használhatják ezeket, ha a klímaváltozás helyi következményeinek katasztrófavédelmi szempontú felmérésében és értékelésében a döntéshozatalt is befolyásolni képes eredményekre van szükségük. 
A projekt célja tehát közös módszertan kidolgozása az éghajlatváltozáshoz köthető kockázatok szisztematikus felmérésére, a társadalom - ezen belül elsősorban a helyi közösségek - klímaadaptációs képességének és veszélyhelyzeti felkészültségének javítására. A klímaváltozás helyi szinten nem „csupán” katasztrófahelyzeteket eredményezhet, hanem olyan szélsőséges időjárási helyzeteket is, amelyekhez már középtávon szükséges alkalmazkodnia a lakosoknak, a gazdasági szereplőknek, a döntéshozóknak és az intézményeknek. Az adaptáció az éghajlatváltozással összefüggő károk mérséklése és a klímaváltozás hatásaira való érzékenység csökkentése érdekében tett intézkedések összessége (Bukovics 2005, 2011; Metzger, Leemans, Schröter 2004; Schmidt 2010). A projekt eredményei végső soron hozzájárulnak ahhoz, hogy a közép- és délkeleteurópai országok katasztrófavédelmi szervei a jövőben hatékonyan felkészülhessenek a klímaváltozás következtében gyakrabban jelentkező és intenzívebbé váló természeti veszélyhelyzetekre, a szélsőséges időjárás okozta természeti katasztrófák kockázatának elemzésére és kezelésére, valamint a lakosság megfelelő felkészítésére.

Az esettanulmányok során a partnerországok tesztelték a klímaváltozásból eredő kockázatok felmérésének és a társadalmi tudatosság mérésének közös módszertanát (1. ábra).

A közös módszertan elméleti megalapozása során a hangsúly az integrált szemléleten és az interdiszciplináris eszközök együttes alkalmazásán volt annak érdekében, hogy a vizsgált rendkívül komplex jelenséggel összefüggő életszerű, valóságos, a hétköznapi életben hasznosítható következtetésekre (is) alkalmasak legyenek a kutatási eredmények (1. ábra).

1. ábra: Az esettanulmányok kutatási tevékenységeinek összefüggései a SEERISK projektben, a társadalomtudományi vonatkozások kiemelésével

Interconnections of research activities in SEERISK pilot studies highlighting relevance of social sciences

\begin{tabular}{|}
\begin{tabular}{|c|c|}
\hline \multicolumn{2}{|c|}{ Kockázatértékelés és a társadalmi kockázattudatosság felmérése } \\
\hline $\begin{array}{c}\text { A) kockázatértékelés és } \\
\text { kockázati térképezés }\end{array}$ & $\begin{array}{c}\text { B) a társadalmi tudatosság és } \\
\text { felkészültség felmérése }\end{array}$ \\
\hline C) az eredmények szintézise \\
\hline \\
hiányosságok és problémák feltárása \\
\hline \\
\hline
\end{tabular} \\
\hline
\end{tabular}


A kockázati felmérés (kockázatértékelés és kockázati térképezés) (A) kezdetén minden mintaterület kiválasztotta a vizsgálandó természeti veszélytípust és annak értékelési szempontját, vagyis a káresemény által okozott negatív hatások jellemzésére használt tényezőt. Ezt követően meghatározták azoknak az adatoknak a legszűkebb halmazát, amelyek nélkülözhetetlenek a különböző kockázattípusok térinformatikai módszerekkel történő elemzése, térképezése során. A projektpartnerek összegyüjtötték az elérhető adatforrásokat, valamint kidolgozták a lehetséges veszély- és hatásszintek mintaterületre vonatkozó kategorizálását, a kockázati mátrixot. Végül a téradatok átalakításával, integrálásával és elemzésével elkészültek a részletes veszélyesség-, hatás- és kockázati térképek, statikus és interaktív webalapú formátumban egyaránt.

A klímaváltozás helyi következményeinek társadalmi vonatkozásait (B) két dimenzióban vizsgáltuk különböző társadalomtudományi módszerekkel: az egyik az egyéni és így a lakossági, a másik az intézményi, döntéshozói szint, amelyek kölcsönös függésben vannak egymással. A lakossági kérdőíves felmérés ${ }^{4}$ célja a lakosok klímaváltozással kapcsolatos tudásának, információszerzési forrásainak, a veszélyeztetettségérzés egyéni értékelésének és a klímaváltozással összefüggő természeti veszélyhelyzetekre való felkészültségének vizsgálata volt. A lakossági felkészültség szorosan összefügg az azt kondicionáló közösségi, intézményi és egyéb döntéshozói problémafelismeréssel és a kapcsolódó beavatkozásokkal. A klímaváltozás intézményi dimenzióinak vizsgálatát egységes módszertant követve hajtották végre a partnerek: legalább négy interjút bonyolítottak le, elsősorban különféle szervezetek vezetőivel, katasztrófavédelmi szakemberekkel és helyi döntéshozókkal (pl. polgármesterekkel), olyan alanyokkal, akiknek a témához való hozzáállása, szervezőereje és befolyása hatással van a helyi közösség tudatosságának formálására és a fejlesztések klímatudatos irányítására. A módszertan kiemelten kezelte a szervezetek közötti kapcsolatok, együttműködések és lehetséges szinergiák feltárását, elemzését. A dokumentumelemzés a települési vagy önkormányzati szintű alapdokumentumok elemzését jelentette, és azt vizsgálta, hogy mennyiben része a klímatudatosság és a veszélyekre való felkészültség a települések fejlesztésének.

Következő lépésként elvégeztük a kockázati felmérés és a társadalmi vizsgálatok eredményeinek szintézisét (C) egyrészt témakörönként, másrészt a teljes kutatás szintjén. A szintézis feltárta a partnerországok közös tulajdonságait és sajátosságait a klímaváltozás helyi hatásaiban, a helyi közösségek felkészültségében és ezek összefüggéseiben. Vagyis meghatároztuk a kockázati felmérésben GIS-módszerekkel bizonyított „objektív” veszélyeztetettség és a társadalmi vizsgálatokkal feltárt „szubjektív” veszélyérzet közötti különbségeket.

A szintézis lehetőséget adott a veszélyhelyzeti kitettség és a lakossági, intézményi felkészültség közötti hiányosságok, problémák megismerésére. Ehhez a projekt a gapanalizis ${ }^{5}$ (D) módszerét alkalmazta, azaz azt vizsgálta, hogy az adott kitettségi helyzetben elvárthoz képest milyen szinten van a helyi lakosok és az intézmények felkészültsége. A kockázati felmérés és a társadalmitudatos- 
ság-felmérés eredményének összevetése rávilágított a veszélyekkel szembeni tényleges kitettség és a helyi közösség felkészültségi foka közti eltérésekre.

A gapanalízis módszerének alkalmazásával feltárt hiányosságok és a beavatkozási lehetőségek (a jogszabályi háttér) ismeretében, valamint az általános adaptációs irányelvek figyelembevételével a projekt egyik fö eredménye a társadalmi alkalmazkodóképesség javítását célzó javaslattétel (E) volt a vizsgált térség témában érintett szereplői, döntéshozói felé.

E tanulmány további részei a kockázati (A) és a társadalmi (B) felmérés releváns eredményeit, következtetéseit tartalmazzák. A kockázati felmérés tárgyalása során elsősorban a kockázati térképezés módszertani vonatkozásairól írunk az egyik mintaterület, Siófok példáján keresztül. A társadalmi felmérés ismertetésében kiemeljük azokat az általános megállapításokat, amelyek az általunk használt módszertannal szerzett ismeretekre, tapasztalatokra épülnek, és amelyek a projekt során alkalmasnak bizonyultak a gapanalízis elvégzésére, s így a szakpolitikai javaslattételre.

A projekt értelmezésében módszertanunk a jövőben az ismertetett módszerek egymásra épülése miatt alkalmazható: a komplex kockázatértékelési és társadalomtudományi vizsgálatok fontossági sorrendjét a javaslattételhez szükséges információk köre, valamint a kockázatokkal szembeni kitettség és a felkészültség között feltárt eltérések jelölik ki.

\section{Kockázati térképezés}

A társadalmi viszonyok elemzése önmagában nem mondana semmit, ha nem tudjuk, mihez képest kell felkészültnek lennie a lakosságnak, a települési önkormányzatoknak és az egyéb illetékes országos és helyi szervezeteknek. Ehhez nyújt információkat a kockázati felmérés és térképezés.

A katasztrófakockázatok térképezésének fó célja a veszélyhelyzetek kezelésében részt vevő szereplők számára olyan eredmények és térinformatikai megoldások biztosítása, amelyek hatékonyan alkalmazhatók a különböző alkalmazkodási és veszélyelhárítási feladatok gyakorlati végrehajtásában. A döntéshozók, döntés-előkészítők és beavatkozók információigénye elsősorban az emberélet, továbbá az anyagi javak védelmének tükrében határozható meg, a veszélytípus tér- és időbeli sajátosságainak figyelembevételével. A SEERISK projektben a mintaterületek más-más veszélytípust határoztak meg, amelyeket a közös módszertan adaptációjával elemeztek az általuk fontosnak tartott szempontok szerint (2. táblázat).

A veszélyekből levezetett védekezési feladatok nemcsak a különböző müveleti (döntéshozás, taktikai szint és beavatkozás) és területi (országos, területi, helyi) szintek, hanem a katasztrófakezelés ciklusai szerint is csoportosíthatók. A megelőzés legfontosabb része a lakossági tájékoztatás és a kockázatelemzés; a fel- 
2. táblázat: A mintaterületeken kiválasztott veszélytípusok és a hozzájuk tartozó értékelési szempontok

The natural risks analysed in case studies and the evaluation criteria related to them

\begin{tabular}{|c|c|c|c|}
\hline Ország & Mintaterület & Veszélytípus & Értékelési szempont \\
\hline Bosznia-Hercegovina & Szarajevó-Ilidža & Árvíz & Érintett épületek típusa \\
\hline Bulgária & Velingrad & Erdőtüz & $\begin{array}{l}\text { Érintett erdőterületek } \\
\text { tűzveszélyességi besorolása }\end{array}$ \\
\hline Magyarország & Siófok & Szélvihar & $\begin{array}{l}\text { Épületek tetősérülékenysége és az } \\
\text { érintett lakosság }\end{array}$ \\
\hline Románia & Arad & Hőhullám & $\begin{array}{l}\text { Hőhullámhoz kapcsolódó orvosi } \\
\text { beavatkozások száma }\end{array}$ \\
\hline Szerbia & Magyarkanizsa & Aszály / Vegetációtűz & $\begin{array}{l}\text { A termés gazdasági értéke / } \\
\text { Polgári védelmi besorolás }\end{array}$ \\
\hline Szlovákia & Szenice & Árvíz & Érintett lakosság \\
\hline
\end{tabular}

készülés során a leginkább veszélyeztetett területekre lakosságvédelmi és veszélyelhárítási terveket kell készíteni, továbbá intézkedéseket szükséges tenni a katasztrófavédelmi erőeszközök készenlétbe állításával. Az esetlegesen bekövetkező katasztrófa miatti beavatkozásnál meg kell tervezni és szervezni a kimenekítést, a kitelepítést és a mentést; az átmeneti működés időszakára és az eredeti állapot helyreállítására terveket kell készíteni, valamint további intézkedéseket hozni. Mindeközben az érintett állampolgárok maguk is aktív közremüködőkké válnak, hiszen a személyes felkészültség, az egyéni veszélytudatosság és az önkéntes segítségnyújtás saját hatáskörben tett vállalásuk eredménye.

A térképezés kiindulópontját az Európai Bizottság Risk assessment and mapping guidelines for disaster management ajánlása alapján (Európai Bizottság 2010), valamint a projektben partnerként részt vevő Bécsi Egyetem munkatársainak vezetésével kidolgozott módszertan (Papathoma-Köhle, Promper, Glade 2013) jelentette. A gyakorlati megvalósítás során több mintaterületen is önállóan kellett kifejleszteni azokat az elemzési eljárásokat, amelyekkel a rendelkezésre álló, változatos minőségü adatforrásokból el lehetett készíteni a tematikus (veszélyességi, hatás- és kockázati) térképeket (Papathoma-Köhle, Promper, Glade 2014).

Mindezt befolyásolta a mintaterületekhez választott természeti kockázatokról rendelkezésre álló adatok köre, típusa ${ }^{6}$ és jellege. A térbeli felbontás és kiterjedés, továbbá az elérhető téradatok kvalitatív vagy kvantitatív jellege behatárolja a kockázatértékelés részletességét és pontosságát. A veszélyességi és hatásszintek meghatározásakor a kvantitatív téradatok elemzése mennyiségi mutatókat ad eredményül, míg a kvalitatív elemzés kevésbé egzakt, a szakértők által becsült tényezőkre, besorolásokra támaszkodik.

Az alkalmazott módszer helyi szintű módosításokat igényelt, ezért a társadalmi vizsgálatokkal ellentétben nem a projekt általános tanulságait mutatjuk be, hanem az egyik mintaterület, Siófok kockázati térképezését ismertetjük, amelyet a Belügyminisztérium Országos Katasztrófavédelmi Főigazgatóság Informatikai Főosztály Térinformatikai és Távközlési Osztályán végeztünk (2. ábra). Az ada- 
2. ábra: A szélviharok kockázati térképezésének általános logikai vázlata

Logical steps of mapping the risk of thunderstorms

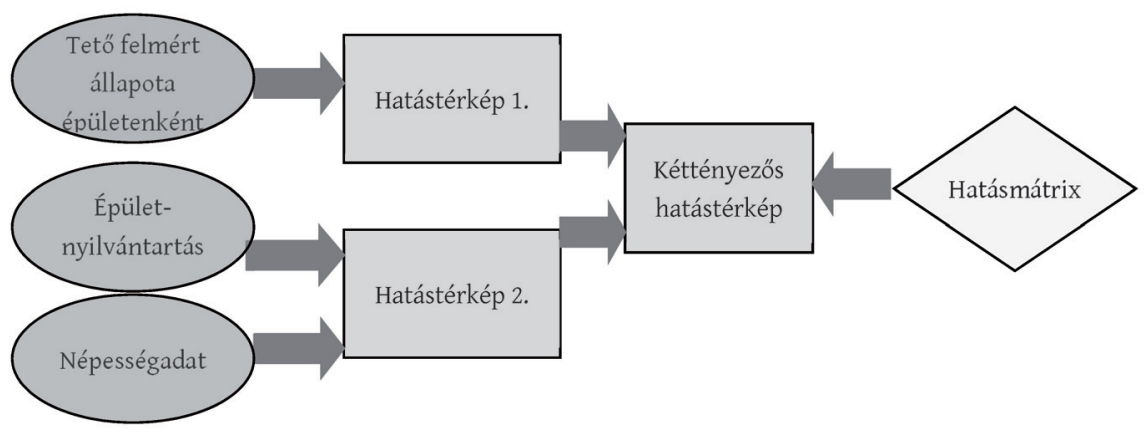

tok alapján elkészült hatástérképekből és a hatásmátrixból kéttényezős hatástérképet készítettünk. A siófoki mintaterületen a szélvihar a kiemelt jelentőségü természeti veszély, mert az elmúlt években érzékelhetően megnövekedett az időjárási esemény gyakorisága és intenzitása, amit az Országos Meteorológiai Szolgálat siófoki viharjelző obszervatóriumának időjárás-megfigyelési adatai is bizonyítanak. A helyi katasztrófavédelmi kirendeltség műveleti adatai alapján pedig az elmúlt években megnőtt a jelentősebb károkat okozó viharok, szélviharok száma a településen. Ezt a tényt a helyi lakosság körében végzett kérdöíves felmérés eredményei és az intézményi interjúk tapasztalatai is igazolták, vagyis a heves esőzéssel járó szélviharok nem csupán súlyosbodtak, hanem kiszámíthatatlanabbá is váltak a városban.

Mivel a szélviharokról - a siófoki viharjelző obszervatórium szakembereinek véleménye szerint - ilyen kis mintaterületre nem állíthatók elő valós térbeli különbségeket ábrázoló intenzitásadatok, veszélyességi térképet nem lehetett készíteni. ${ }^{7}$ Annak érdekében, hogy ekkora területen különbségeket lehessen kimutatni, háromdimenziós terepmodellre lett volna szükség, amely például sztereo légifotópárok feldolgozásával, esetleg a GoogleStreetView siófoki utcaképeinek bejárása során elvégzett épületmagasság-kategorizálással vagy a napjainkban sajnos még rendkívül költséges légi LIDAR-felmérés eredményeivel állítható elő. Ilyen digitális terepmodell pedig akár városon belüli széláramlási modellek, szélmezőtérképek generálására is lehetőséget biztosítana.

Mindezek hiányában is Siófok városa igen sokféle információt bocsátott rendelkezésre a hatástényezőkről, a település épületállományáról és az épületekben lakók számáról, így a szélviharok károkozó hatásait két szempont, az épületek tetősérülékenysége és az érintett lakosok száma alapján lehetett értékelni. Az így elkészült két hatástérkép összegzésével kéttényezős hatástérképet állítottunk elő. Az elemzési műveletekben vektoros adatforrást használtunk (3. táblázat), vagyis a kockázatértékelés alapegységét az épületpoligonok jelentették.

Mindezek mellett Siófok városa elvégezte a kétféle hatástényező kategorizálását, s azokra építve megalkotta a kockázatértékelés során használt kétté- 
3. táblázat: A siófoki kockázati térképezés során felhasznált adatok Data used for the Siófok risk mapping

\begin{tabular}{ll}
\hline \multicolumn{1}{c}{ Adatforrás } & \multicolumn{1}{c}{ Magyarázat } \\
\hline Eltérő tetőállapotú városi térségek & Területfoltok az épületek tetóállapota szerint \\
Épület-nyilvántartás & Telekhatárok és épületek határainak vonalrajza \\
Népességadat & Egyedi lakcímekhez rendelt lakosságszámok \\
\hline
\end{tabular}

nyezős hatásmátrixot: a vízszintes tengelyen a tetősérülékenység (hatásszint 1), a függőleges tengelyen pedig az érintett lakosságszám (hatásszint 2) hatásszintjeivel (3. ábra).

A tetősérülékenység alapján készült hatástérképen (4. ábra) az épületpoligonok három kategóriába kerültek, a területet jól ismerő önkormányzati szakértőktől kapott kvalitatív adatok alapján. Ennek eredményeként minden épülethez hatásszintet rendeltünk (Magas [2], Alacsony [1], Jelentéktelen [0]).

3. ábra: Siófok kéttényezős hatásmátrixa

Two-dimensional impact matrix of Siófok

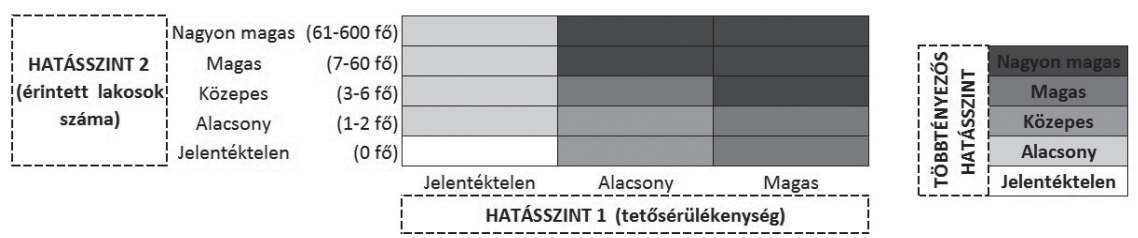

4. ábra: Siófok hatásszint 1-térképe a tetősérülékenység alapján, kinagyított részlettel Impact map 1 of Siófok, based on the vulnerability of roofs

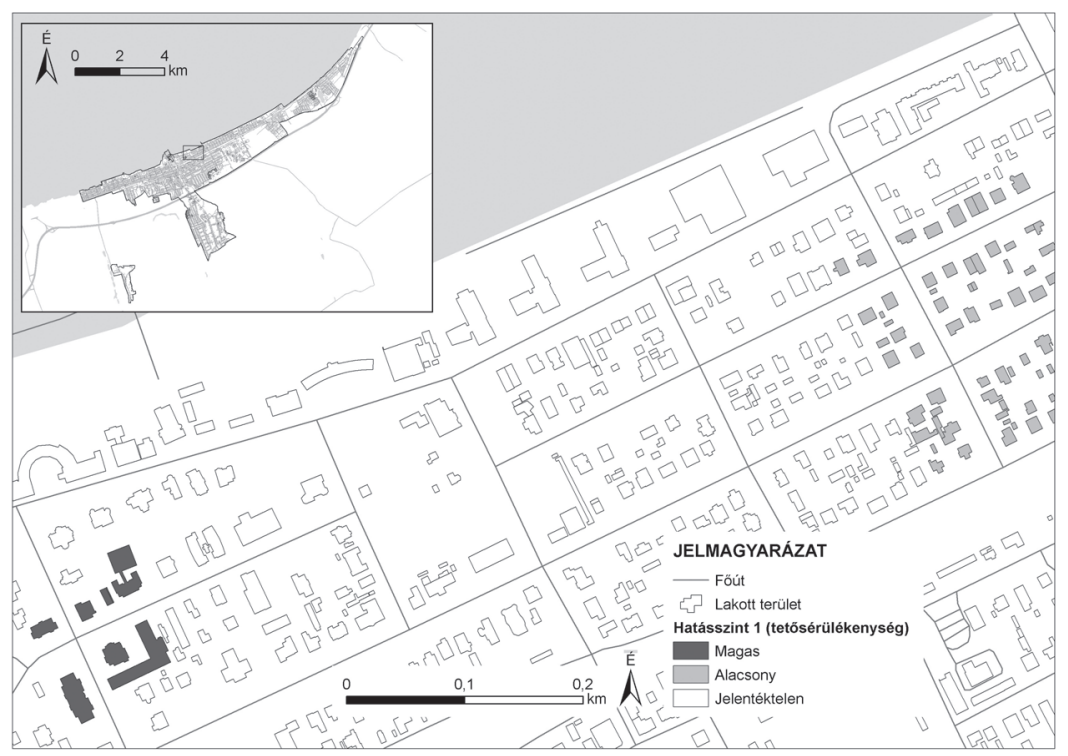


A tetőállapot-felmérés során a Siófoki Közös Önkormányzati Hivatal építész szakértői elsősorban az épületek állagát, építőanyagát, a tetők és kémények anyagát, állapotát vették figyelembe. Az alacsony hatáskategóriába egyrészt a part menti övezetekben található, jó állapotú épületek (mivel ez a terület lombhullató fákkal és feketefenyőkkel sűrűn telepített, amelyek kidőlése gyakran okoz tetősérüléseket), másrészt régebbi, gyengén karbantartott tetőszerkezettel rendelkező épületek kerültek. A magas hatáskategóriába azok a területek tartoznak, ahol jellemzően elhanyagolt fedett felszínek, présházak vagy egyéb építmények, valamint 40 évnél régebbi faépületek fordulnak elö. Amennyiben a későbbiekben még részletesebb adatok állnak rendelkezésre, a kvalitatív hatásmátrix helyett akár kvantitatív hatásgörbék is készíthetők (Cechet et al. 2012). Az épületpoligonokhoz hozzárendelt lakosságszámot ábrázoló hatástérképen (5. ábra) kimenekítési szempontú osztályozást készítettünk, öt kategóriával (61-600 fö = Nagyon magas [4], 7-60 fö = Magas [3], 3-6 fö = Közepes [2], 1-2 fö = Alacsony [1], 0 fö = Jelentéktelen [0]).

Ezek a kategóriák az érintett lakosságszámot mutatják, a leggyakoribb élethelyzetekhez igazodva: a kétfős háztartástól a nagycsaládokon és társasházi-lépcsőházi létszámokon át a közintézmények befogadóképességi maximumáig. A védekezés és mentés tervezése során lényeges információ, hogy néhány ötfös család vagy esetleg egy egész szálloda érintett pl. 80-100 fövel. Ezen túlmenően a kialakítandó átmeneti befogadó szállás méretét is ki lehet számolni az érintett lakosok száma alapján.

5. ábra: Siófok hatásszint 2-térképe az érintett lakosok száma alapján, kinagyított részlettel Impact map 2 of Siófok, based on the number of inhabitants

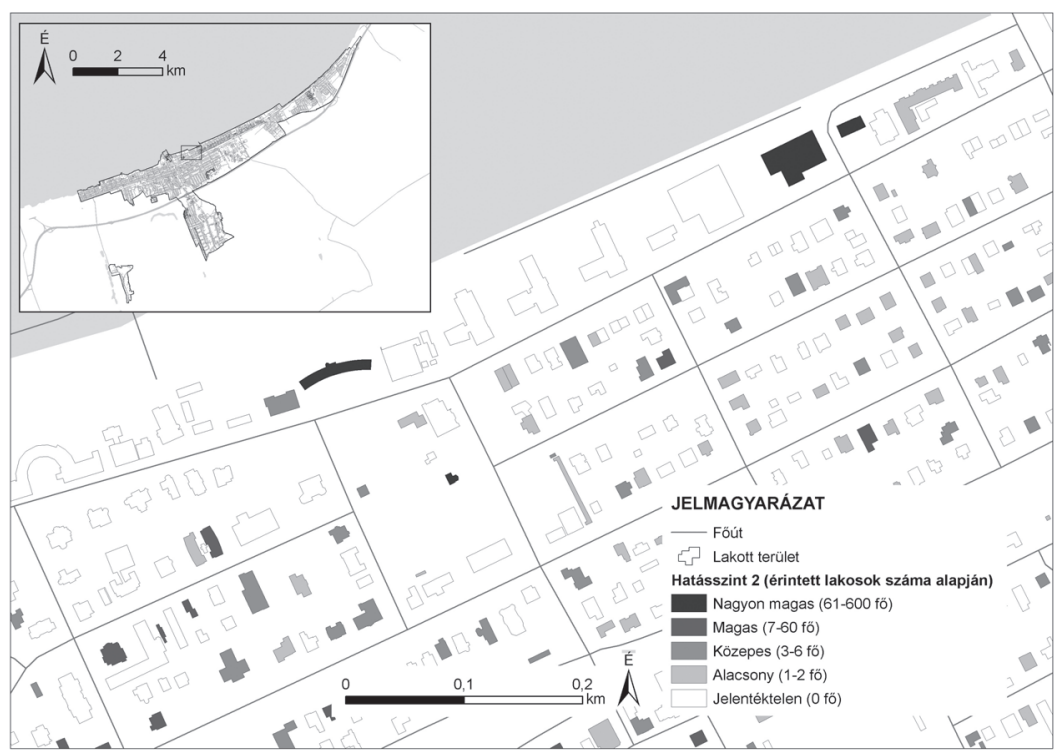


A kockázati térképezés utolsó lépése a kéttényezős hatástérkép (6. ábra) elő́llítása volt, a hatásmátrix (3. ábra) felhasználásával. Ezt helyiértékes összeadással valósítottuk meg: a kéttényezős hatásértéket az 1. hatásérték tízszeresének és a 2. hatásértéknek az összege adja. Az eredményül kapott két számjegyü értékekből a hatásmátrixban négy kategóriát alakítottunk ki, a 3. ábrán látható színezésnek megfelelően. Például ha egy épület tetősérülékenysége magas [2], lakosainak száma pedig alacsony [1], akkor a helyiértékes összeadással számított kéttényezős hatás értéke $10 \times 2+1=21$, ami a hatásmátrix alapján magas kéttényezős hatásszintnek felel meg, ezért ez az épület a 6. ábrán is a magas hatásszintnek megfelelő színű poligonként jelenik meg.

Így a múltbeli tapasztalatokból meghatározott tetősérülékenységi kategóriák, valamint az egyes épületekben érintett népesség száma mindenki által könnyen értelmezhető, kéttényezős hatástérképet eredményez, a hatásmátrix színkódolása jelmagyarázatként használható.

A térinformatikai elemzés térképei (4-6. ábra) hasznosíthatók a mintaterület kockázati forgatókönyvének elkészítésénél. A kockázati térképek a katasztrófakezelés megelözési és felkészülési szakaszaiban felhasználhatók azon területek kijelölésében, ahol erő-összpontosításra vagy megelőzési munkálatokra lehet szükség. A beavatkozások megtervezéséhez és a védelmi tervek elkészítéséhez szintén hasznos segítséget nyújtanak, de szűkített adattartalommal akár lakossági tájékoztatási célokat is szolgálhatnak.

6. ábra: Siófok kéttényezős hatástérképe (tetősérülékenység és érintett lakosság),

kinagyított részlettel

Impact map of Sioffok with the two factors combined

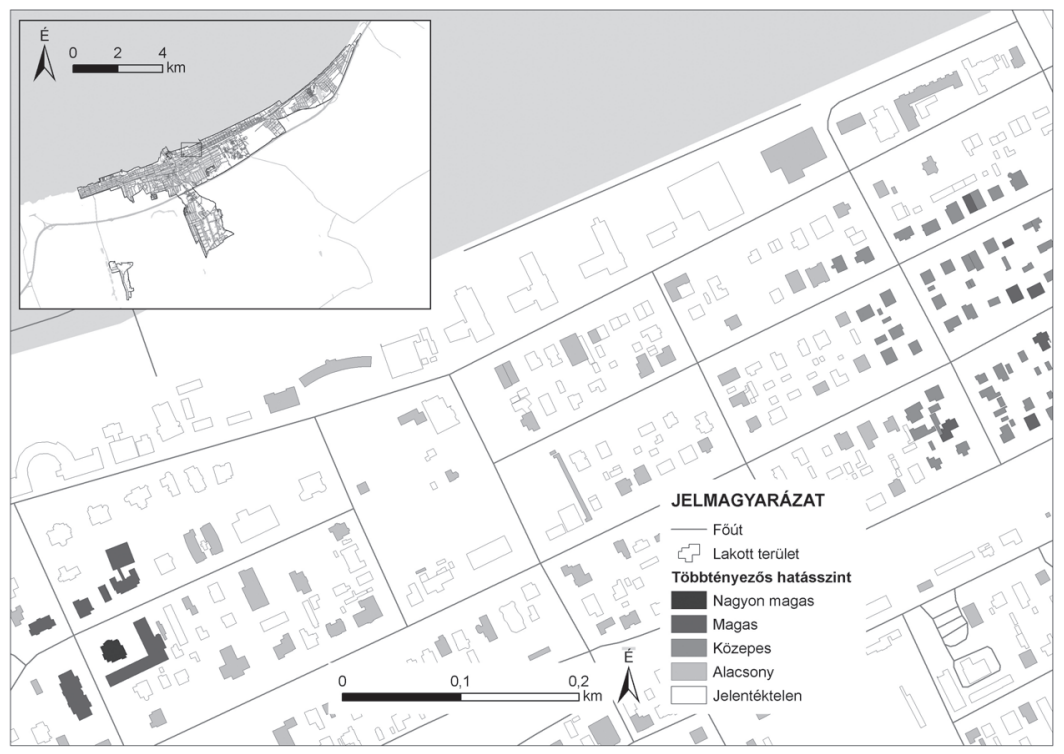


Mindezek mellett az eredmények webes környezetben, interaktív térképalkalmazások létrehozásával is elérhetők a felhasználók számára, az Országos Katasztrófavédelmi Főigazgatóság szerverén. ${ }^{8}$ Ezzel a korszerű megoldással a katasztrófakezelésben részt vevő tűzoltók és polgári védelmi erők könnyen, felhasználóbarát felületen tájékozódhatnak a vizsgált terület sajátosságairól, egyben térbeli áttekintést kaphatnak az esetlegesen zajló beavatkozásokról. Például Siófok bármely épületéről lekérdezhető annak tetőállapota és lakóinak száma, valamint az ezek kombinációjaként meghatározott kéttényezős hatásszintje. Igény szerinti nagyítású részletek kinyomtatására szintén lehetőség van a webes térképalkalmazásból, a beavatkozók akár papíron is magukkal vihetik a terepre a legfontosabb információkat.

A projektben kidolgozott, térinformatikai alapokra épülő gyakorlati módszertan újszerű megoldást nyújt a katasztrófakockázatok elemzéséhez, ami egyaránt növeli a tervezés, a megelőzés és a beavatkozás hatékonyságát, eredményesen járulhat hozzá a lakossági és vagyonvédelemhez a katasztrófák elleni védekezés során.

Fontos megjegyezni, hogy az ismertetett térképek tartalmának értelmezéséhez, valamint a katasztrófavédelmi intézkedések megtervezéséhez szükség van arra a tudásra is, amelyet a Siófokon elvégzett társadalomtudományi vizsgálatok adnak. Például a 4. és a 6. ábrán markánsan kirajzolódik két olyan terület a város déli részén, ahol magas a hatásszint, vagyis amelyek veszélyeztetett területek. A terepbejárás, valamint az elkészített interjúk alapján kiderült, hogy ezekben a városrészekben alacsonyabb társadalmi státuszú lakosság él, ahol a lakásminőség a korlátozott anyagi erőforrások miatt szembeötlően kedvezőtlenebb. A kockázati térképezés (tetősérülékenység és érintett lakosságszám) alapján legveszélyeztetettebb területek némileg eltérnek a helyi lakosok és intézmények által leginkább sérülékenynek definiált területektől. A kérdőíves felmérésben megkérdezett siófoki lakosok másként vélekedtek a helyi veszélyeztető tényezőkről: a Balaton közelében élók magasabb arányban jelezték természeti veszélyhelyzetnek a hőséghullámokat, míg a külvárosban, lazább beépítésủ részen élők a szélviharokat tartják veszélyeztetőnek, amelyeket a káresemények között is megneveztek. A szakértői interjúk pedig megerősítették, hogy a szélsőséges időjárási jelenségek közvetlen és közvetett - pl. tavon keresztül érvényesülő - hatásai alapján kitettsége és mélyebb fekvése miatt a tóparti sáv a legveszélyeztetettebb terület. Ezt a területet a vasútvonal határolja dél felől, elzárva a belvárostól, s ezzel megnehezíti és akadályozza a viharok esetén szükségessé váló kimenekítést.

\section{Klímatudatosság és felkészültség}

A klímaváltozás társadalmi összefüggéseinek legismertebb hazai kutatási előzményei kérdőíves felméréseikben legtöbbször a lakosság klímaváltozással kap- 
csolatos attitüdjét vizsgálták (pl. Faragó, Láng, Csete 2010; Kovács, Szépszó, Szabó, Krüzselyi 2012; Szirmai 2009). Ugyan már az ezredfordulótól megszaporodtak az olyan elméleti munkák, amelyek a lakosság sérülékenységét a klímaváltozással összefüggő katasztrófahelyzetek oldaláról elemezték (pl. Bukovics 2008; Kovács, Szépszó, Szabó, Krüzselyi 2012; Teknős 2009), mégis kevés olyan empirikus vizsgálat született, amely a közösségi felkészültségre helyezte volna a hangsúlyt. Kérdőíves felmérésünk általános és mintaterület-specifikus eredményei hozzájárulnak az emberek klímaváltozással és természeti veszélyhelyzetekkel kapcsolatos attitüdjének megismeréséhez.

A SEERISK projekt a helyi léptékű kockázatfelmérés módszertani eszköztárában a kérdőíves felmérést a társadalom veszélyeztetettségtudatának és a klímaváltozáshoz kapcsolódó természeti veszélyhelyzetekre való felkészültségének megismerésére alkalmazta, az alábbi témakörök vizsgálatával:

- A globális klímaváltozással kapcsolatos tudás és az azzal kapcsolatos információszerzés forrásai.

- Az egyéni biztonságérzet és a természeti veszélyhelyzetek általi veszélyeztetettség értékelése, személyes tapasztalatok a természeti katasztrófákkal kapcsolatban.

- A természeti veszélyhelyzetekre való felkészülés és a megelőzés különböző formái.

A hat mintaterület felméréseinek eredményeiből megállapítható, hogy egyrészt a megkérdezett lakosok bizonytalanok a klímaváltozás lokális következményeinek értékelésében, másrészt az életkor és az iskolai végzettség hatással van a megszerzett tudás alkalmazására: a magasabb életkor és az alacsonyabb iskolai végzettség az összefüggések felismerését részben csökkenti, míg a tapasztalati megfigyelések befolyásoló szerepét erősítheti.

A klímaváltozással és a katasztrófavédelemmel kapcsolatban a megkérdezettek legfontosabb információforrásai a hagyományos kommunikációs eszközök, különösen a televízió. A modern kommunikációs eszközök (pl. mobiltelefon, internet, közösségi oldalak) szignifikánsan a 35 év alatti városlakók számára elsődleges információforrások (a mintaterületek közül pl. Aradon, Siófokon) (Földi, Uzzoli 2014). Az írott sajtó jelentősége leginkább az országos napilapokon és újságokon keresztül jelenik meg, míg a helyi sajtóorgánumok elsődlegesen a periferikus helyzetű vidéki területeken jelentenek információforrást a lakosok számára (pl. Szarajevó-Ilidža, Szenice). Az előzetes várakozások ellenére az oktatás szerepét alacsonynak értékelték a megkérdezettek, s inkább a magasabb iskolai végzettséggel rendelkezőknek fontosabb információforrás.

A megkérdezettek döntő többsége nem tudja pontosan eldönteni, hogy milyen mértékben hatnak a természeti veszélyhelyzetek a biztonságérzetükre, az viszont tény, hogy a veszélyeztetettségérzés az életkorral növekszik, leginkább 60 év felett. Azok között, akik átéltek már valamilyen katasztrófahelyzetet, markánsan magasabb azok aránya, akik folyamatosan veszélyeztetve érzik magukat. A rossz lakáskörülmények között, a hátrányos társadalmi környezetben élők érzik leginkább magukat veszélyeztetve a természeti veszélyhelyzetek által. 
A válaszadói vélemények alapján leggyakrabban megnevezett természeti veszélyhelyzetek együttesen tükrözik az emberek tapasztalatait, a média által hangoztatott információkat (pl. Lőrincz 2010) és a megszerzett ismeretek készségszintủ alkalmazását. Néhány mintaterületen egyszerre több természeti kockázat is megjelent a válaszok között (pl. Arad, Magyarkanizsa, Szenice), mert az elmúlt években több természeti veszélyhelyzet is sújtotta ezeket a területeket. Máshol nincs nagy különbség a válaszok megoszlásában (pl. Velingrad): itt az egységesebb válaszadás annak tulajdonítható, hogy az elmúlt években általában mindig ugyanaz a természeti veszélyhelyzet alakult ki a területen.

A természeti veszélyhelyzetekre való felkészülésben, a megelözésben és a klímaváltozás következményeinek enyhítésében csaknem hasonló lépéseket tesznek a lakosok, ebben nincs jelentős különbség az országok között. A személyes kompetencia és a háztartások anyagi helyzete erőteljesen meghatározza a lakosok preventív magatartását, így a személyes hatáskörben kivitelezhető óvintézkedések megvalósítása az életkörülményektől és a jövedelemszinttől függ. Általában megfigyelhető, hogy a klímaváltozás szerepe megjelenik a megelőzéssel és felkészüléssel kapcsolatos egyéni döntéshozatalban. A klimatikus adottságok helyi átalakulásához való lakossági alkalmazkodás legszembetűnőbb jelei a vizsgált mintaterületeken a kérdőíves felmérés alapján a nyílászárók (időjárásálló, hővédő ablak és ajtó) cseréje, a hővédő roló, redőny használata, a klímaberendezés beépítése, a lakás vagy a ház fizikai állapotának rendszeres ellenőrzése, a ház tetőzetének megerősítése, a hőszigetelés.

A helyi szereplők (intézmények, döntéshozók) klímatudatosságának és felkészültségének vizsgálata félig strukturált interjúkkal zajlott. Az interjúk egységes kérdéssora a klímaváltozás helyi szintű kezelésére, valamint a katasztrófa- és polgári védelemi vonatkozásokra fókuszált. Az interjúalanyok kiválasztása a helyi kompetenciák alapján történt. A vizsgálatba olyan, vezető pozícióban lévő személyeket (pl. polgármester, foépítész, polgári védelmi felelős, iskolaigazgató, klímaváltozással foglalkozó NGO vezetője) vontunk be, akiknek lehetősége és kötelessége helyi szintű döntéseket hozni a klímaváltozással kapcsolatos felkészülésről és az adaptációs lépésekről. Véleményük megismerése fontos, mert hozzáállásuk, tájékozottságuk a kulcs a szükséges döntések meghozatalában és a pénzügyi források biztosításában. Az eredményeket öt kiemelt témakörben foglaljuk össze.

Az interjúalanyok véleménye a klímaváltozás érzékelhető helyi hatásairól mintaterületenként változó volt. Siófokon, Aradon, Magyarkanizsán és Szarajevó-Ilidžában az interjúalanyok egyetértettek abban, hogy az időjárás átalakulása a klímaváltozás helyi hatásaiból következik, míg Velingradban és Szenicében ezt inkább az időjárás természetes ciklikus változásának tulajdonították. Szükségesnek ítélték, hogy további vizsgálatok támasszák alá a globális klímaváltozás és a helyi szinten mind gyakoribbá váló szélsőséges időjárási helyzetek közötti összefüggést.

A klímaváltozással és védekezéssel kapcsolatos információk átadásában - az interjúalanyok véleménye alapján - a különféle szereplők (önkormányzatok, is- 
kolák, egészségügyi szolgálatok, helyi katasztrófavédelmi szervezetek) együttes bevonására van szükség. Ideális esetben ez többszereplős tevékenység, amelynek keretében a központilag (törvényileg) meghatározott és helyileg kezdeményezett felkészítő akciók (iskolai rendezvények, kiadványok, gyakorlatok) kombináltan jelennek meg a lakosság különböző csoportjainak életében. Az egyes szereplők közötti kooperáció minden mintaterületen elvárásként jelent meg, miközben a valós együttmüködések és közös akciók, valamint azok hatékonysága erősen különbözik a mintaterületeken. Az együttműködésre léteznek jó példák, például Siófokon több interjúalany is beszámolt pozitív kezdeményezésekről, bár ezek hatékonyságát nem ítélték egyértelmüen sikeresnek.

Az interjúalanyok a prevenciós tevékenységek növekvő jelentőségét támasztották alá minden partnerországban. Hangsúlyozták, hogy a prevenciós tevékenységeket korosztály-specifikusan szükséges végezni és ebben a helyi média lehetőségeit még nagyobb mértékben kellene kiaknázni. A felelős vezetők és szakemberek lényegében minden mintaterületen egyetértettek abban, hogy a felkészítés és tájékoztatás fó célcsoportját a fiatalkorúak jelentik, mivel ők érhetők el a leggyorsabban és legkönnyebben intézményesített formában (pl. iskola). Tapasztalataik szerint a középkorú népességet a legnehezebb megszólítani a felvilágosító akciókkal: számukra az országos és helyi médiumok a legfontosabb információforrások, de a speciális, helyi vonatkozású ismeretek átadásában ezek hatékonysága alacsony szintű. Egyes esetekben fontossá válik speciális célcsoportok, pl. éttermi, szállodai dolgozók felkészítése. Ez az igény Siófokon és Velingradban is jelentkezett, mivel mindkét város kiemelt turisztikai célpont, ahol nemcsak a helyi lakosság, de az ideiglenesen városban tartózkodók épségére is figyelni kell a szélsőséges időjárási helyzetekben. További figyelmet érdemel, hogy az egy-egy település határain belül, de többnyire annak periferikus részein koncentrálódó alacsonyabb státuszú lakosság felkészítése eltéro” stratégiát és speciális eszközöket igényel.

A partnerek beszámolói szerint a lakosság általában nem különösebben érdeklődik a klímaváltozással kapcsolatos, a hétköznapi életet érintő és alkalmazkodást igénylő változások, illetve az ezekre való felkészülés iránt. Az interjúk szerint a lakosság nem kellően felkészült a katasztrófahelyzetekre. Ez a témakör - főleg a hátrányosabb helyzetű vidéki térségekben - a háztartások szintjén kiesik a napi szintü megoldandó problémák köréből. Az ismeretek hiánya, a közöny és a nemtörődömség szélsőséges viselkedési formákat is ölthet: ilyen a helyi építési szabályzat figyelmen kívül hagyása (pl. Szarajevó-Ilidža), a közterületek önérdekü használata (pl. parkolók kialakítása esővíz-elvezető csatornák betömésével - Siófok) vagy egyszerüen a magántulajdonú ingatlanok elhanyagolása. Mindezek szélsőséges időjárási helyzetekben komoly következményekkel járnak.

A klímasajátosságok és a klímaváltozás hatása a városfejlesztésre és városüzemeltetésre nagyon eltérő megítélésű a mintaterületek különféle jellege (város vagy várostérség) és az egyéb adottságok miatt. Általában mindenki egyetért abban, hogy a kritikus infrastruktúra, mint a víz- és áramellátás, az utak, a védőgátak 
élveznek elsőbbséget a fenntartási feladatok és fejlesztések között. A szélsőséges időjárási események pl. Siófokon olyan stratégiai fontosságú rendszereket is érintenek, mint a Balaton vízgazdálkodásának műtárgyai vagy a vasúthálózat. Ezek fenntartása és fejlesztése természetesen nem a város hatáskörébe tartozik, ugyanakkor a károsodásuk helyben jelenthet problémát. Fontos tehát a különféle területi hatáskörü szakági szervezetekkel, hivatalokkal való kapcsolattartás és együttműködés. Szenice a folyóvízhez kötődően tartja fontosnak a védmüvek, gátak védelmét, fejlesztését. Aradon a hőhullámok elleni védekezésben nagy jelentőséget kapnak a lakó- és középületek hőszigetelési, a zöldterületek fejlesztési programjai. Magyarkanizsa környékén az agrártermeléshez kapcsolódóan az öntözőrendszerek kiépítését, a csatornahálózat megújítását és bővítését priorizálják.

Az interjúk mellett az egyes partnerönkormányzatok fejlesztési dokumentumainak áttekintésére volt szükség ahhoz, hogy pontosan megértsük, város- és területfejlesztési szempontból mennyiben tudatos a klímaváltozás hatásaira történő felkészülés. Fontos vizsgálati szempont volt, hogy a tervezési folyamat egyes fázisaiba mennyire épülnek be a klímaváltozás helyi vonatkozásai és a potenciális helyi hatások kezelése. A klímaváltozás uniós szinten átrendezte a fejlesztési prioritásokat és ez a támogatási források allokációját is nagyban befolyásolja. Egyre sürgetőbb, hogy a SEERISK projektben résztvevő EU-tag és tagjelölt országokban a város- és területfejlesztés alapdokumentumai következetesen rögzítsék a klímaváltozással összefüggő helyi adottságokat és fejlesztési szükségleteket.

A vizsgált rendezési tervek (szerkezeti terv, szabályozási terv, helyi építési szabályzat stb.) a klímaváltozás témakörével külön nem foglalkoznak, ok-okozati viszonyokat nem tárnak fel. A klímaváltozás következményeinek kezelése nagyon lassan és indirekt módon kerül be az ilyen jellegü dokumentumokba.

A helyi fejlesztési programok (terület- és településfejlesztési koncepciók, programok, integrált település- és térségfejlesztési stratégiák stb.) ugyanakkor jelentős potenciállal bírnak a téma iránti érzékenység tervezésbe történő beépítésére. A klímaváltozás helyi vonatkozásait értékelő elemzés elkészítése és a kapcsolódó fejlesztési szükségletek meghatározása még nem elterjedt gyakorlat a délkelet-európai térségben. Az elemzések alapján elmondható, hogy az átfogó, több szektort is érintő fejlesztési tervek a klímaváltozást esetlegesen és legtöbbször csupán a környezeti állapot értékelésénél tárgyalják. A tervezés éghajlati vonatkozású hiányosságait a partnerek azzal magyarázták, hogy az érintett országokban a top-down tervezési gyakorlat érvényesül, és így a helyi integrált fejlesztési dokumentumok jelentős időbeni átfutással, a magasabb területi szintek integrált és szakági fejlesztési dokumentumaihoz igazodva készülnek el. A hazai tervezésben a vonatkozó jogszabály szerint a téma már kötelező eleme a településfejlesztési stratégiáknak.

A jelenleg érvényben lévő dokumentumokban definiált fejlesztési beavatkozások indoklása többnyire nem a klímaváltozás hatásain alapszik, még akkor 
sem, ha valójában amiatt váltak szükségessé. A jövőben mindenképpen nagyobb mértékben kell figyelembe venni a klímaváltozás helyi hatásaiból eredő szükségleteket, nem feltétlenül külön fejlesztési prioritásként, hanem horizontális tervezési szempontként, pl. a közintézmények és lakóépületek energiatudatos fejlesztésénél, amely mind a mitigáció, mind pedig a klímaadaptáció céljaihoz hozzájárulhat. A fejlesztési dokumentumok a forrásszerzés megalapozói az uniós tagországokban. Az Európai Unió a 2014-2020-as időszakban különféle pénzügyi alapjain keresztül kiemelten támogatja a tagországokban a klímaváltozáshoz kapcsolódó befektetéseket, ami motiválhatja a téma helyi priorizálását.

A szakági, tematikus tervek (környezetvédelmi programok, klímavédelmi tervek stb.) a klímaváltozás témakörének fontos megjelenítői. A vizsgált mintaterületek többsége nem rendelkezik ilyen tervekkel helyi szinten. Ez a dokumentumtípus az ok-okozati összefüggések rendszerében a klímaváltozás okaira koncentrál és főleg mitigációs intézkedéseket - pl. alacsony $\mathrm{CO}_{2}$-kibocsátású rendszerek alkalmazása - tartalmaz. A helyi klímaváltozással kapcsolatos stratégiák egyelőre nem jelennek meg kulcsfontosságú eszközként, viszont a projektpartnerek már rendelkeznek országos szintű stratégiákkal, amelyek az elmúlt években kezdtek el adaptációs kérdésekkel is foglalkozni, és az uniós célokhoz és irányelvekhez igazodnak.

Témánk szempontjából kiemelten fontos volt az egyes mintaterületeken eltérő névvel illetett, de pontosan definiált jogszabályi kötelezettségen alapuló katasztrófavédelmi tervek vizsgálata. Ezek elsősorban operatív jellegűek, beavatkozásorientáltak és a helyi klimatikus adottságok miatt kialakult katasztrófahelyzetek megoldására (is) koncentrálnak. Nem céljuk az ok-okozati összefüggések feltárása, s a klímaváltozás befolyásoló szerepét csak néhány mintaterület katasztrófavédelmi terve említi (pl. Arad, Siófok, Szarajevó-Ilidža). Általános megfigyelés volt, hogy valamennyi mintaterület katasztrófavédelmi terve hangsúlyozza a megelőzés és a megfelelő lakossági felkészítés, mindezekkel összefüggésben pedig az együttműködések jelentőségét. A katasztrófavédelmi tervek alig utalnak más helyi tervezési dokumentumok tartalmára, ha mégis, akkor elsősorban a településszerkezeti, területrendezési tervre. A dokumentumelemzés részeként a szabályozási környezet dokumentumainak (katasztrófavédelmi törvények, határozatok, rendeletek stb.) tartalomelemzését is elvégeztük. Összességében megállapítható, hogy jelentősebb jogszabályi változások minden partnerországban történtek az elmúlt években, amelyek alapvető átalakulást hoztak a korábban különálló katasztrófavédelem, polgári védelem és tűzoltóság szervezeti rendszerében. Az átalakulás részben integrációs, részben pedig centralizációs folyamatokat jelentett, és célja a múködési hatékonyság növelése volt.

A társadalmi vizsgálatok segítségével meghatározhattuk a részben vagy egészében klímaváltozásból eredeztethető kockázati helyzetekre adott intézményi és lakossági válaszok hiányosságait (gapanalízis). A hiányosságok pontosításával végül javaslatokat tudtunk megfogalmazni. 


\section{Összefoglalás - Zárszó}

A klímaváltozás hatásainak kezelése és az azokhoz történő alkalmazkodás új szemléletet és változatos (nem feltétlenül forradalmian új, de korábban kevéssé alkalmazott) kutatási módszereket igényel. Ezek megvalósítása - az általános irányelveken túl - helyi szintű ismereteket és vizsgálatokat feltételez. Az okokozati összefüggések és kölcsönhatások feltárása holisztikus megközelítésben kivitelezhető, ami multidiszciplináris eszközök alkalmazását teszi szükségessé. A SEERISK projekt természet- és társadalomtudományi vizsgálati technikákat ötvözött, egyben a gyakorlatban tesztelte az egyes módszereket közép- és délkelet-európai mintaterületeken. A projekt fó eredménye a klímaváltozással összefüggésben a veszélyeztetettség, valamint a társadalmi tudatosság mérésének egységes elven alapuló és adaptálható módszertanának kidolgozása.

A kutatás során számos előre nem látható helyzet adódott, amelyekre végül a projektben nem lehetett végső megoldást találni, viszont a későbbiekben szükséges lenne ezekre is reflektálni a közös módszertan továbbfejlesztésében, a helyi adottságokhoz igazodó módosításában. A kockázati térképezésben a legtöbb problémát az adatszűkösség, valamint a veszélyeztetettség léptéke (helyi vagy térségspecifikus) és térbeli kiterjedése (mérete) jelentette. Mind a kockázati felmérésben, mind pedig a társadalmi vonatkozások vizsgálatában érzékelhetően különvált a klímaproblematika (a klímaváltozás tényének bizonyítása) és következményeinek kezelése (lakossági és intézményi felkészülés, megelőzés, katasztrófavédelem). Ugyan egyre több információnk van az éghajlatváltozásról (hidrometeorológiai szolgálatok adatai, klímamodellek, forgatókönyvek), de keveset tudunk a klímaváltozás helyi kockázatairól, és általában csak formális, alacsony hatékonyságú az illetékes szervezetek együttműködése. Mindezek a társadalmi tudatosság és felkészültség vizsgálatában is utolérhetők voltak: a kvalitatív úton szerzett tapasztalatok szubjektivitásának kiszürése megköveteli a részletesebb, alaposabb terepismeretet, amelyet a jövőben hasonló kutatások elvégzéséhez javaslunk (pl. közös terepbejárások és terepi munkák). A klímaváltozás és helyi következményeinek komplexitása megköveteli az integrált gondolkodást, valamint a többszereplős együttműködést és cselekvést: ez a szemlélet a projekt célkitűzéseinek és módszereinek kidolgozásában előtérbe került, de a gyakorlati tapasztalatok alapján inkább az elmélet szintjén maradt. A területi vizsgálati szint és a földrajzi lépték kiválasztása szintén kulcskérdés hasonló kutatás, projekt szervezése során: a közös módszertant ugyan a lokális vizsgálatokhoz ajánljuk, ennek értelmezését és kijelölését viszont a vizsgált veszélytípus terjedelme határozza meg, vagyis a regionális elemzéseknél szükséges a társadalmi szereplők körét bővíteni, kiegészíteni.

A klímaváltozás globális összefüggéseket takar, hatásai természetszerűleg a közösségek szintjén jelentkeznek. A globális és helyi folyamatok kapcsolatának felismerése a kutatások alapján kezdeti stádiumban tart, nemcsak a lakosság, hanem a felelős intézmények és döntéshozók szintjén is. Az intézményesült 
válaszok késnek, ez megnyilvánul a lakosság felkészültségében és a veszélyek érzékelésének alacsony szintjében. A lemaradás nem kevés problémát okoz az éghajlatváltozásokra való felkészülés és a hatásokkal szembeni védekezés hatékonyságának területén. A kutatás tanúsága szerint a délkelet-európai térség különösen veszélyeztetett, hiszen a fejlett EU-tagokhoz képest olyan társadalmi problémákkal és infrastrukturális lemaradásokkal küszködik, amelyek a klímaváltozás hatásainak kivédését csak kockázati vagy katasztrófahelyzetekben engedi elötérbe helyezni.

A SEERISK projekt összességében felhívja a figyelmet a makroregionális tudásmegosztás és közös módszertanok alkalmazásának fontosságára annak érdekében, hogy a társadalmi-gazdasági felzárkózás a jövőben már a klímatudatosság figyelembevételével és az általános irányelvek integrálásával történjék.

\section{Köszönetnyilvánítás}

A tanulmány az Európai Unió támogatásával, a SEERISK - Közös katasztrófavédelmi kockázatértékelés és felkészülés a Duna makrorégióban (SEE/C/0002/2.2/X SEERISK) nemzetközi projekt keretében készült el.

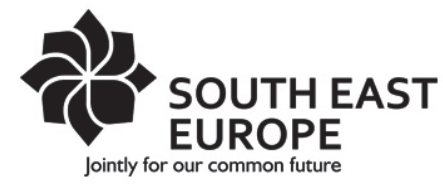

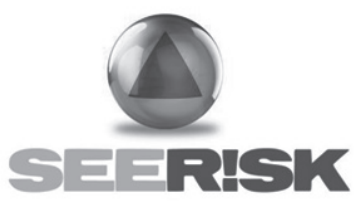

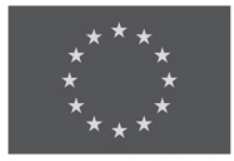

Programme co-funded by the EUROPEAN UNION

\section{Jegyzetek}

1 A nemzeti éghajlatváltozási stratégia (NÉS és NÉS2) elkészítését az ENSZ éghajlatváltozási keretegyezménye és annak kiotói jegyzőkönyve végrehajtási keretrendszeréről szóló 2007. évi LX. törvény (V. 28.) 3. §-a írja elő. A nemzetközi kötelezettségvállalásokkal összhangban első alkalommal a 2008-2025-ös időszakra kellett kidolgozni az éghajlatváltozási stratégiát. A NÉS célkitűzéseit - a kétévenként kidolgozott - nemzeti éghajlatváltozási programok valósítják meg. A NÉS illeszkedik a kormány által az 1054/2007 (VII.9.) kormányhatározatban elfogadott nemzeti fenntartható fejlődési stratégiához is (NÉS2 2013; NÉS 2008).

2 A Belügyminisztérium Országos Katasztrófavédelmi Főigazgatóság (BM OKF) az Európai Unió Délkelet-európai Transznacionális Együttműködési Programjának (SEE Program) keretében nemzetközi projektet indított 2012-ben. Ennek végrehajtásában aktív szerepet vállalt szakértő partnerként a Magyar Tudományos Akadémia Közgazdaság- és Regionális Tudományi Kutatóközpont Regionális Kutatások Intézete (MTA KRTK RKI).

3 A projekt partnerországai: Ausztria, Bosznia-Hercegovina, Bulgária, Horvátország, Magyarország, Románia, Szerbia, Szlovákia, Szlovénia.

4 A kérdőíves felmérés összesen 1644 kérdőívre épült utcai megkérdezéssel, amelyet a partnerek 2013. június és szeptember között bonyolítottak le. A megkérdezés véletlenszerü volt, a 
kérdőívek kitöltése kb. 25-30 percet vett igénybe. A felmérés során az adott mintaterület lakosságának 1\%-a került be a vizsgálatba, így az eredmények a helyi lakosság életkorára és iskolai végzettségére nézve nem reprezentatívak. Adott mintaterületen a lakóhely típusai alapján (pl. belváros, külváros, vegyes beépítésủ terület, külterület stb.) további mintavételi egységeket jelöltünk ki, ahol népességarányos volt a megkérdezések száma. Az adatok összesítését és az eredmények szöveges elemzését - előre megadott szempontrendszer alapján - a projektpartnerek végezték el, a szintézis elkészítése pedig az MTA KRTK RKI feladata volt.

$\mathrm{Az}$ üzleti és marketingtervezésben gyakorta használt modell a gapanalízis, más néven réselemzés. A módszer a jövőbeli célokat és a várható teljesítményt hasonlítja össze, és az eltérés kiküszöbölésére próbál megoldásokkal szolgálni (Babbie 2001). A módszer általánosan elterjedt a SWOT-analízis helyettesítőjeként a térbeli, társadalmi jelenségek vizsgálatánál is, jellemzően a meglévő és a kívánt (ideális) állapot közötti különbség definiálására használható, amelyből szakmai javaslattétel vezethető le.

6 A térinformatikai adatformátumok két alapvető típusa a raszter és a vektor. A raszteres adat pixelekből áll, amelyek terepi mérete határozza meg a részletességet. A vektoros adat pontokat, vonalakat vagy poligonokat tartalmazhat, általában azok leíró tulajdonságaival (attribútumaival) együtt.

7 A többi mintaterület nagysága és az elemzett természeti veszélyek típusa ezt máshol lehetővé tette (http://www.seeriskproject.eu/seerisk/\#maps).

\section{Irodalom}

Babbie, E. (2001): A társadalomtudományi kutatás gyakorlata. Balassi Kiadó, Budapest

Bukovics I. (2005): A klímapolitikai döntések katasztrófavédelmi és kockázatelméleti kérdései. Magyar Tudomány, 7., 842-848.

Bukovics I. (2008): Felkészülés a klímaváltozásra: Környezet - Kockázat - Társadalom témájú kutatás aktualitása. Védelem Online, http://www.vedelem.hu/letoltes/tanulmany/tan160.pdf (Letöltés: 2014. március 14.)

Bukovics I. (2011): Klímaadaptáció és toleranciabizonytalanság. Alkatelméleti vizsgálat. In: Tamás P., Bulla M. (szerk.): Sebezhetőség és adaptáció - A reziliencia esélyei. MTA Szociológiai Kutatóintézet, Budapest, 65-96. https://jak.ppke.hu/uploads/articles/11851/file/Sebezhet\%C5\%91s\%C3\%A9g_ teljes\%20k\%C3\%B6tet.pdf (Letöltés: 2014. február 17.)

Cechet, R. P., Sanabria, L. A., Divi, C. B., Thomas, C., Yang, T., Arthu, W. C., Dunford, M., Nadimpalli, K., Power, L., White, C. J., Bennett, J. C., Corney, S. P., Holz, G. K., Grose, M. R., Record Gaynor, S. M., Bindoff, N. L. (2012): Climate futures for Tasmania: Severe wind hazard and risk - Technical report. Geoscience Australia, 43., http://www.ga.gov.au/corporate_data/74052/Rec2012_043.pdf (Letöltés: 2014. március 23.)

Európai Bizottság (2010): Risk Assessment and Mapping Guidelines for Disaster. Management. Commission Staff Working Paper, Brüsszel http://ec.europa.eu/echo/civil_protection/civil/pdfdocs/prevention/COMM_PDF_SEC_2010_1626_F_staff_working_document_en.pdf (Letöltés: 2014. március 23.)

Faragó T., Láng I., Csete L. (2010): Climate change and Hungary: Mitigating the hazard and preparing for the impacts („The VAHAVA Report”). Budapest http://www.vahavahalozat.hu/files/vahava-201012-korrigalt-2.pdf (Letöltés: 2014. február 27.)

Földi Zs., Uzzoli A. (2014): A társadalom veszélyhelyzeti felkészültsége - Egy siófoki esettanulmány tapasztalatai. Védelem Online, 3., http://www.vedelem.hu/index.php?pageid=hirek_reszletek\& hirazon=1631 (Letöltés: 2014. április 1.)

Kovács M., Szépszó G., Szabó P., Krüzselyi I. (2012): Kérdőiv a klímaváltozásról. http://www.met.hu/doc/ omsz_hirek/2012.02.15/Klimavaltozas_kerdoiv_ertekeles-2012.02.pdf (Letöltés: 2014. március 13.) 
Lőrincz D. (2010): Az elveszett kríziskommunikáció nyomában, avagy a média hatalma a kommunikációban. In: Schmidt P. (szerk.): Környezeti problémák a Kárpát-medencében. II. Nemzetközi Klímakonferencia Tanulmánykötet. Publikon Kiadó, Pécs, 183-188.

Metzger, M. J., Leemans, R., Schröter, D. (2004): A multidisciplinary multi-scale framework for assessing vulnerability to global change. Millennium Ecosystem Assessment Conference. http://www.maweb.org/documents/bridging/papers/metzger.marc.pdf (Letöltés: 2014. február 10.)

NÉS (2008): Nemzeti éghajlatváltozási stratégia 2008-2025. http://www.terport.hu/teruletfejlesztes/ orszagos-szint/fejlesztesi-dokumentumok/nemzeti-eghajlatvaltozasi-strategia-2008-2 (Letöltés: 2014. július 7.)

NÉS2 (2013): Második nemzeti éghajlatváltozási stratégia 2014-2025, kitekintéssel 2050-re. http://nak.mfgi.hu/sites/default/files/files/NES_final_131016_kikuld_kozig_egyeztetes.pdf (Letöltés: 2014. július 14.)

Papathoma-Köhle, M., Promper, C., Glade, T. (2013): SEERISK: Common risk assessment methodology for the Danube macro-region. http://rsoe.hu/projectfiles/ seeriskother/download/common_risk_ assessment_methodology.pdf (Letöltés: 2014. július 7.)

Papathoma-Köhle, M., Promper, C., Glade, T. (2014): SEERISK: A risk assessment methodology for climate change related hazards - mapping heatwave risk in Romania. EGU General Assembly. http:// meetingorganizer.copernicus.org/EGU2014/EGU2014-3459.pdf (Letöltés: 2014. július 7.)

Pappné Vancsó J. (2014): Éghajlatváltozás és emberi alkalmazkodás a középkori meleg időszakban A sikeres alkalmazkodás attribútumai. Földrajzi Közlemények, 2., 107-121.

Schmidt P. (2010): Éghajlatváltozás, és ami mögötte van, avagy a szcenáriók katasztrófavédelmi aspektusai. In: Schmidt P. (szerk.): Környezeti problémák a Kárpát-medencében. II. Nemzetközi Klímakonferencia Tanulmánykötet. Publikon Kiadó, Pécs, 178-182.

SEERISK (2014a): Guideline on climate change adaption and risk assessment in the Danube macro-region. http://rsoe.hu/projectfiles/seeriskOther/download/climate_change_adaptation.pdf (Letöltés: 2014. július 7.)

SEERISK (2014b): Klímaadaptációs és kockázatértékelési kézikönyv a Duna makrorégióra. http://rsoe.hu/projectfiles/seeriskother/download/klimaadaptacios_kezikonyv_print.pdf (Letöltés: 2014. július 7.)

Szirmai V. (2009): Az éghajlatváltozás lehetséges térbeli társadalmi hatásai, a magyar társadalom klímatudatossága, sérülékenysége, alkalmazkodása. Klíma 21. Füzetek, 64. http://www.nfft.hu/ dynamic/Az_eghajlatvaltozas_tarsadalmi_hatasai_klimatudatossag.pdf (Letöltés: 2014. február 28.)

Teknős L. (2009): A globális klímaváltozás és a katasztrófavédelem kapcsolata - avagy a katasztrófavédelem reagálása az új kihívásokra Magyarországon. Hadmérnök, 2., 80-94. http://hadmernok.hu/2009_2_teknos.php (Letöltés: 2014. március 11.) 